https://helda.helsinki.fi

\title{
Laparoscopic versus open nephrectomy for renal cell carcinoma?
}

\section{Taari, Kimmo}

2004

Taari , K , Perttilä , I \& Nisén , H 2004 , ' Laparoscopic versus open nephrectomy for renal cell carcinoma?' ', Scandinavian Journal of Surgery, vol. 93 , no. 2 , pp. 132-136.

http://hdl.handle.net/10138/297735

publishedVersion

Downloaded from Helda, University of Helsinki institutional repository.

This is an electronic reprint of the original article.

This reprint may differ from the original in pagination and typographic detail.

Please cite the original version. 


\title{
LAPAROSCOPIC VERSUS OPEN NEPHRECTOMY FOR RENAL CELL CARCINOMA?
}

\author{
K. Taari ${ }^{1}$, I. Perttilä ${ }^{1}$, H. Nisen ${ }^{2}$ \\ 1 Department of Urology, Helsinki University Hospital, Helsinki, Finland \\ 2 Section of Urology, Jorvi Hospital, Helsinki University Hospital, Espoo, Finland
}

Keywords: Kidney; nephrectomy; laparoscopy; carcinoma; renal cell

\section{INTRODUCTION}

Renal cell carcinoma (RCC) accounts for $3 \%$ of all cancers (1) in adults and is the third commonest urological malignancy. Incidence of RCC has been shown to rise in USA (2) and Europe (3). In Finland the incidence of RCC is now 9.5 per 100,000 /year in men, and in the next 10 years it is estimated to increase by $20 \%(4)$. The male to female ratio is $3: 2$ and in $4 \%$ of cases the tumours are bilateral (5). A higher incidence is well noted in patients with von Hippel-Lindau syndrome and other genetic alterations (6). The overall 5-year survival rate is $60 \%$.

The increased incidence of RCC is primarily due to enhanced detection of tumours by expanded use of imaging techniques. During the last ten years the rate of incidentally detected renal tumours has increased to $60 \%$ (7). Robson presented the operative principles of radical nephrectomy in the 1960s, which became the "gold standard" treatment for localised RCC (8). Since Clayman and colleagues in 1990 performed their first laparoscopic nephrectomy (9), the method has reached increasing enthusiasm and evolved to become the standard in the near future. The stage migration into small, low-stage tumours has changed the open surgical treatment strategy towards the direction of nephron sparing surgery (10), and the first laparoscopic nephron sparing wedge resection was described by McDougall and colleagues in 1993 (11).

\section{RADICAL NEPHRECTOMY}

\section{OPEN TECHNIQUE}

The standard technique of open radical nephrectomy (ORN) includes early control of hilar vessels, removal of kidney with perirenal fat and Gerota's fascia (12). It has been suggested that the removal of ipsilateral adrenal gland is not necessary if the tumour is located in the lower pole of the kidney or is smaller that $5 \mathrm{~cm}$ in diameter (13). Lymphadenectomy allows for more accurate pathological staging, but its therapeutic value remains controversial (10). Open radical nephrectomy can be performed transperitoneally or extraperitoneally.

\section{LAPAROSCOPIC TECHNIQUE}

Laparoscopic radical nephrectomy (LRN) follows the same oncological principles as the open operation with regard to early vessel control, total specimen removal, adrenalectomy and lymphadenectomy (14). The laparoscopic operation is more frequently done through a transabdominal route than through an extraperitoneal route. Access to the abdominal hole is created with the help of a Verres needle or via a minilaparotomy. Renal artery is usually clipped and the renal vein stapled and cut. Ultrasound knife is found by many to be a useful instrument with minimal bleeding. The specimen is taken out in an endobag through a suprainguinal or midline muscle-splitting incision. In the hand-assisted technique (15) the abdominal incision for evacuating the specimen is utilized during the whole operation making the procedure more easy and quick.

\section{INDICATIONS}

Kimmo Taari, M.D.

Department of Urology

Helsinki University Hospital

P.O. Box 580

FIN - 00029 HUS, Finland

Email: kimmo.taari@hus.fi
According to the Scandinavian Urological Association Collaboration Group for Renal Cancer survey in 1998 (16), 60 \% of all Scandinavian urological departments performed less that 20 nephrectomies per year 
and overall $24 \%$ performed less than five operations per year. With these limited numbers, the surgical strategy must be relatively easy and straightforward. Accordingly, the open radical nephrectomy (ORN) is still the standard approach for most general urologists when faced with a solid tumour in one kidney and a functionally normal contralateral kidney. In Finland, the retroperitoneal approach was used for standard nephrectomy in $56 \%$ of the departments, in contrast to the transperitoneal approach used in $85 \%$ of the departments in other Nordic countries (16).

The indications for laparoscopic radical nephrectomy (LRN) are basically the same as for the open one. However, tumours bigger than $10 \mathrm{~cm}$ can be too difficult to handle with the present laparoscopic instruments (17). Obesity is not a contraindication for laparoscopic procedures, and obese patients may even benefit more than the slim ones from laparoscopic approach in respect to postoperative pain and morbidity (18). In accordance with some other reports (19), we have found the hand-assisted technique as a safe way to start laparoscopic surgery and also as a good way to expand the indications to more difficult tumours as well as more obese patients. In experienced hands, laparoscopy has already replaced the open radical surgery in local renal tumours (20). Hand-assisted technique incorporating the advantages of standard and laparoscopic approach will hopefully expand the indications and make the technique realistic in general urological level.

\section{OPERATIVE OUTCOME}

Operative outcome is here discussed in terms of operative time, estimated blood loss, rate of conversion and complications.

\section{OPERATIVE TIME}

Mean operative time of LRN varies from 149 to 414 minutes and is significantly longer than the duration of the open procedure in reported comparative studies (Table 1). However, with hand-assisted technique the operative times have been similar with those of open procedure $(21,22)$ and shorter than those of the standard laparoscopy (23).

\section{BLOOD LOSS DURING OPERATION}

Due to magnified vision and positive intra-abdominal pressure, bleeding is less during a laparoscopic than an open operation. This is well documented in two comparative studies $(27,22)$. The estimated blood loss in LRN groups was $172-183 \mathrm{ml}$, and in ORN groups 263-451 ml.

\section{COMPLICATIONS}

In older series concerning ORN, postoperative complications occurred in about $20 \%$ of patients and the operative mortality was about $2 \%$ (28). Haemorrhage from renal vessels, duodenal rupture for the rightsided operation and splenic and pancreatic lesions for the left-sided operation are the most important ones. Intercostal neuralgies, muscular relaxation and wound dehiscence are not rare after a lumbotomy.

In some contemporary series, complications after laparoscopic nephrectomy were reported in 9.6-14\% $(14,17,29)$. The typical complications include haemorrhage from renal veins or the spleen, bowel ruptures, port problems like bleeding, infection and hernias. Puncture with Verres needle when creating pneumoperitoneum rarely results in vascular damage. However, most of the complications in open as well as in laparoscopic operations can be avoided with increasing familiarity with the techniques (17). Conversion rates due to the perioperative complications vary between $0 \%$ and $10 \%$. Laparoscopy may induce some cardiopulmonary effects; intra-abdominal pressure compresses veins and decreases cardiac and urine output. There is also a risk for pulmonary embolism.

\section{MORBIDITY}

Patients recover better and quicker after LRN than after open surgery. Postoperative morbidity is here discussed in terms of hospital stay, postoperative pain and need of analgesics and time to normal activity.

\section{HOSPITAL STAY}

In all comparative studies the number of postoperative days after LRN is significantly less than that after ORN (Table 2).

TABLE 1

Operative time in comparative studies between open radical nephrectomy (ORN) vs laparoscopic radical nephrectomy ( $L R N)$.

\begin{tabular}{lccc}
\hline REF. & Number of patients & ORN (min) & LRN (min) \\
\hline$(24)$ & 100 & 198 & 312 \\
$(25)$ & 24 & 132 & 414 \\
$(26)$ & 29 & 128 & 149 \\
$(21)$ & 36 & 118 & $221^{*}$ \\
$(22)$ & 104 & 181 & $195^{*}$ \\
\hline
\end{tabular}

* = Hand-assisted

TABLE 2

Hospital stay in comparative studies between open radical nephrectomy $(O R N)$ vs laparoscopic radical nephrectomy (LRN).

\begin{tabular}{lccc}
\hline REF. & Number of patients & ORN (days) & LRN (days) \\
\hline$(27)$ & 94 & 5.2 & 3.4 \\
$(25)$ & 24 & 8.4 & 4.5 \\
$(26)$ & 29 & 7.6 & 3.2 \\
$(21)$ & 36 & 5.1 & $3.9^{*}$ \\
$(22)$ & 104 & 8.9 & $6.8^{*}$ \\
\hline
\end{tabular}

\footnotetext{
* $=$ Hand-assisted
} 


\section{POSTOPERATIVE PAIN}

The need for pain relief is estimated in morphine equivalents $(\mathrm{mg})$ and is reported in comparative studies to be significantly diminished after LRN compared to that after ORN (Table 3).

TABLE 3

Need of narcotic equivalents in comparative studies between open radical nephrectomy (ORN) vs laparoscopic radical nephrectomy (LRN).

\begin{tabular}{lccc}
\hline REF. & Number of patients & ORN (mg) & LRN (mg) \\
\hline$(27)$ & 94 & 78.3 & 28.0 \\
$(25)$ & 24 & 40 & 24 \\
\hline
\end{tabular}

TABLE 4

Time to normal activity in comparative studies between open radical nephrectomy (ORN) vs laparoscopic radical nephrectomy (LRN).

\begin{tabular}{lccc}
\hline REF. & Number of patients & ORN (weeks) & LRN (weeks) \\
\hline$(24)$ & 100 & 8.1 & 3.3 \\
$(27)$ & 94 & 8.1 & 3.6 \\
$(25)$ & 24 & 5.1 & 3.5 \\
$(26)$ & 29 & 4.3 & 2.0 \\
$(21)$ & 36 & 23.5 & $15.8^{*}$ \\
\hline
\end{tabular}

* = Hand-assisted

TABLE 5

5-year Kaplan-Meier estimates of disease-free survival in comparative studies between open radical nephrectomy (ORN) vs laparoscopic radical nephrectomy (LRN).

\begin{tabular}{lccc}
\hline REF. & Number of patients & ORN (\%) & LRN (\%) \\
\hline$(32)$ & 263 & 87 & 91 \\
$(33)$ & 149 & 95.1 & 89.7 \\
$(34)$ & 133 & 91 & 92 \\
\hline
\end{tabular}

TABLE 6

Indications for nephron-sparing surgery for renal cell carcinoma (10).

Imperative indications

Tumour in solitary kidney Renal agenesis

Prior surgery or trauma

Bilateral renal tumours

Multifocal tumours in patients with familial RCC

Relative indications

Diabetes, nephrosclerosis

Tumour with contralateral

Renal artery stenosis

Hydronephrosis

Recurrent pyelonephritis

Calculous disease

Elective indications

Incidental renal tumour $<4 \mathrm{~cm}$ Normal contralateral kidney

\section{CONVALESCENCE}

Time to normal activity after LRN is reported to be $2-15.8$ weeks and is significantly shorter than after ORN. In comparative studies, the mean time to normal activity is diminished by $31-59 \%$ (Table 4 ).

\section{ONCOLOGICAL LONG-TERM RESULTS}

The risk of postoperative recurrent malignancy and the chances of cure are strongly stage- and gradedependent (30). The incidence of recurrence or metastatic disease after ORN is about $7 \%$ for T1N0M0, $26 \%$ for T2N0M0, and $39 \%$ for T3N0M0 tumours (10). Actuarial long-term results of patients with T1-2 tumours are not yet available from laparoscopic series but the Kaplan-Meier estimates for 5-year recurrence-free survival of $89-92 \%$ have been reported (Table 5). Occasional port site recurrences have been noted (31), but this seems to be very rare and caused by tumour spillage during operation. The oncological results are actually equivalent after ORN and LRN for T1-2 tumours.

\section{COST COMPARISON}

During the learning phase, laparoscopic operations required more time leading to extra costs. Some recent studies have shown that the better convalescense of patients and comparable operating times have already translated into LRN to be a cost effective operation compared to ORN (35-37).

\section{NEPHRON-SPARING SURGERY}

\section{INDICATIONS}

The indication for nephron-sparing surgery (NSS) can be categorized as imperative, relative or elective (Table 6). Interest in elective NSS for RCC has grown during the last decades because of improved renal imaging and a growing number of patients with small peripheral tumours. Comparative studies have shown that renal function is better preserved after NSS than after radical nephrectomy $(38,39)$. In selected cases of small $(<4 \mathrm{~cm})$ peripheral lesions, nephron-sparing surgery may be indicated $(39,40)$, but patients with bigger tumours are generally considered as candidates for radical nephrectomy.

\section{TECHNIQUE OF OPEN NEPHRON-SPARING SURGERY}

The access to the kidney for partial nephrectomy is most often an extraperitoneal flank incision (41). The kidney is completely mobilized on the hilar vessels. This must enable clamping of the vessels whenever necessary during the operation. If one does expect a warm ischaemia time of less than 30 minutes, in the presence of a normal contralateral kidney, the resection can be done without cooling. If cooling is necessary, slush ice is applied on the kidney surface resulting in a decreased oxygen need during the ischaemic phase of the operation (41). It is advised 
to apply a standard cooling time of 20 minutes or more before resection.

For the resection, the cold knife and conventional surgical instruments can be used although ultrasound aspiration or waterjet dissectors, laserbeam, microwave tissue coagulator and other tools have been proposed. However, none of them has shown any advantage over the conventional techniques.

In an elective situation, with normal contralateral kidney, tumour resection should always be attempted within healthy parenchyma. Tumour enucleation relying on the tumour pseudocapsule cannot be recommended even in patients with small tumours. For peripheral tumours, a wedge resection is preferable $(5,42)$. When there is any doubt about the margin status, frozen sections are obviously mandatory (43, 44). When the incision in the renal cortex is properly planned, one may be able to close the fishmouth defect with interrupted sutures (45). When the parenchymal defect cannot be closed, a haemostatic sponge, fat or omentum can be placed into the defect to provide additional haemostasis.

\section{TECHNIQUE OF LAPAROSCOPIC}

NEPHRON-SPARING SURGERY

Modern approach depends much on the localization of the tumour. For posterior tumours retroperitoneoscopic approach might be adequate but for anterior tumours the transperitoneal route is preferred (14). Ports are typically placed more lateral than in radical nephrectomy. Renal vessels must be controlled before resection and they can be occluded with special clamps. The tumour is resected with scissors and haemostasis to the parenchyma is gained with sutures and bipolar forceps. Fishmouth type defect is closed with suture over a haemostatic sponge (14). Recently, a new gelatin-based matrix thrombin sealant (FloSeal) was used in open and laparoscopic kidney resection with excellent haemostatic results $(46,47)$.

\section{COMPLICATIONS AFTER NEPHRON-SPARING SURGERY}

Partial kidney resection is more liable to complications than radical nephrectomy because of the inherent risk of bleeding, especially in cases with obligatory indications. Haemorrhage can lead to perirenal haematoma, false aneurysm or arteriocalyceal fistula. Selective embolization is usually required in case of haemorrhagic complications. Urinary fistula usually resolves spontaneously under the condition that adequate drainage is guaranteed. In some cases a double J catheter can be inserted or a temporary nephrostomy is helpful. Finally, renal arterial thrombosis can occur because of a lesion of the intima of the renal artery after clamping. However, postoperative complications are reported to be very few in experienced hands $(5,42)$.

\section{RESULTS OF NEPHRON-SPARING SURGERY}

The major debate regarding elective NSS concerns the risk of local recurrence. Incomplete resection is one of the causes of local recurrence while multifocality can also be responsible for a kidney tumour recurrence. Local recurrence is more common after imperative NSS since incomplete resection occurs more often when larger and less circumscribed tumours are treated. Recently, several authors have reported good oncological results of partial open nephrectomy for elective tumours of $4 \mathrm{~cm}$ or less in diameter $(5,42,44,48)$.

Comparative studies between open vs laparoscopic NSS are rare. Gill et al. (49) reported on 100 laparoscopic resections compared with 100 open operations performed in a single institution. Three patients in the laparoscopy group and none in the open group had positive surgical margins. Perioperative and postoperative urological complications were more frequent in the laparoscopy group. In addition, laparoscopic NSS was associated with longer ischemia time. Although morbidity is decreased with the laparoscopic method, open partial nephrectomy remains the established standard for nephron-sparing treatment of renal tumours (20).

\section{SUMMARY}

Laparoscopic radical nephrectomy has become a well-standardized and reproducible, but technically demanding procedure. It is rapidly replacing the traditional open technique in radical nephrectomy with T1-2 tumours. Open operation will mainly be reserved for T3 tumours. Nephron-sparing surgery will play a major role in small $(<4 \mathrm{~cm})$ peripheral tumours. Open technique is still the standard for NSS, but with the refined techniques, laparoscopy may be soon coming.

\section{REFERENCES}

1. Jemal A, Thomas A, Murray T, Thun M: Cancer statistics. CA Cancer J Clin 2002;52:23-47

2. Chow WH, Devesa SS, Warren JL, Fraumeni Jr JF: Rising incidence of renal cell carcinoma in the United States. JAMA 1999;281:1628-1631

3. Kirkali Z, Tuzel E, Mungan MU: Recent advances in kidney cancer and metastatic disease. BJU Int 2001;88:818-824

4. Engeland A, Haldorsen T, Tretli S, Hakulinen T, Horte LG, Luostarinen T, Magnus K, Schou G, Sigvaldason H, Storm HH: Prediction of cancer incidence in the Nordic countries up to the years 2000 and 2010. A collaborative study of the five Nordic Cancer Registries. APMIS suppl 1993;38:1-124

5. Russo P: Renal cell carcinoma: presentation, staging, and surgical treatment. Semin Oncol 2000;27:160-176

6. Maranchie JK, Linehan M: Genetic disorders and renal cell carcinoma. Urol Clin North Am 2003;30:133-141

7. Pantuck AJ, Zisman A, Belldegrun AS: The changing natural history of renal cell carcinoma. J Urol 2001;166:1611-1623

8. Robson CJ, Churchill BM, Anderson W: The results of radical nephrectomy for renal cell carcinoma. J Urol 1969;101:297-301

9. Clayman RV, Kavoussi LR, Soper NJ, Dierks SM, Meretyk S, Darcy MD, Roemer FD, Pingleton ED, Thomson PG, Long SR: Laparoscopic nephrectomy: initial case report. J Urol 1991;146: 278-282

10. Van Poppel H, Deroo F, Joniau S: Open surgical treatment of localised renal cell cancer. EAU Update Series 2003;1:220-225

11. McDougall EM, Clayman RV, Anderson W: Laparoscopic wedge resection of a renal tumor: initial experience. J Laparoendosc Surg 1993;3:577-581 
12. Mickisch G, Carballido J, Hellsten S, Schulze H, Mensink H, European Association of Urology: Guidelines on renal cell cancer. Eur Urol 2001;40:252-255

13. Tsui KH, Shvarts O, Barbaric Z, Figlin R, deKernion JB, Belldegrun A: Is adrenalectomy a necessary component of radical nephrectomy? UCLA experience with 511 radical nephrectomies. J Urol 2000;163:437-441

14. Janetschek G, Jeschke K, Peschel R, Strohmeyer D, Henning $\mathrm{K}$, Bartsch G: Laparoscopic surgery for stage T1 renal cell carcinoma: radical nehprectomy and wedge resection. Eur Urol 2000;38:131-138

15. Wolf Jr JS, Moon TD, Nakada SY: Hand-assisted laparoscopic nephrectomy: technical considerations. Tech Urol 1997;3:123128

16. Mommsen S, Ljungberg B, Einarsson GV, Johnsen J, Kallio J, Nurmi M, Rosenlund AF: Status of pretreatment evaluation, treatment and follow-up regimens for renal cell carcinoma in the Nordic countries. Scand J Urol Nephrol 2003;37:401-407

17. Gill IS, Meraney AM, Schweizer DK, Savage SS, Hobart MG, Sung GT, Nelson D, Novick AC: Laparoscopic radical nephrectomy in 100 patients: a single center experience from the United States. Cancer 2001;92:1843-1855

18. Klingler HC, Remzi M, Janetschek G, Marberger M: Benefits of laparoscopic renal surgery are more pronounced in patients with a high body mass index. Eur Urol 2003:43:522-527

19. Stifelman MD, Handler T, Nieder AM, Del Pizzo J, Taneja S, Sosa RE, Shichman SJ: Hand-assisted laparoscopy for large renal specimen: a multi-institutional study. Urology 2003;61: $78-82$

20. Bhayani SB, Clayman RV, Sundaram CP, Landman J, Andriole G, Figenshau RS, Bullock A, Brandes S, Shalhav A, McDougall E, Kibel AS: Surgical treatment of renal neoplasia: evolving toward a laparoscopic standard of care. Urology 2003;62: $821-826$

21. Nakada SY, Fadden P, Jarrard DF, Moon TD: Hand-assisted laparoscopic radical nephrectomy: comparison to open radical nephrectomy. Urology 2001;58:517-520

22. Lee SE, Ku JH, Kwak C, Kim HH, Paick SH: Hand assisted laparoscopic radical nephrectomy: comparison with open radical nephrectomy. J Urol 2003;170:756-759

23. Nelson CP, Wolf Jr JS: Comparison of hand assisted versus standard laparoscopic radical nephrectomy for suspected renal cell carcinoma. J Urol 2002;167:1989-1994

24. Ono Y, Kinukawa T, Hattori R, Yamada S, Nishiyama N, Mizutani K, Ohshima S: Laparoscopic radical nephrectomy for renal cell carcinoma: a five-year experience. Urology 1999;53: 280-286

25. McDougall E, Clayman RV, Elashry OM: Laparoscopic radical nephrectomy for renal tumor: the Washington University experience. J Urol 1996;155:1180-1185

26. Goel A, Hemal AK, Gupta NP: Retroperitoneal laparoscopic nephrectomy and nephroureterectomy and comparison with open surgery. World J Urol 2002;20:219-223

27. Dunn MD, Portis AJ, Shalhav AL, Elbahnasy AM, Heidorn C, McDougall EM, Clayman RV: Laparoscopic versus open radical nephrectomy: a 9-year experience. J Urol 2000;164:11531159

28. Swansson DA, Borges PM: Complications of transabdominal radical nephrectomy for renal cell cancer. J Urol 1983;129:704707

29. Cadeddu JA, Ono Y, Clayman RV, Barrett PH, Janetschek G, Fentie DD, McDougall EM, Moore RG, Kinukawa T, Elbahnasy AM, Nelson JB, Kavoussi LR: Laparoscopic nephrectomy for renal cell cancer: evaluation of efficacy and safety: a multicenter experience. Urology 1998;52:773-777

30. Giberti C, Oneto F, Martorana G, Rovida S, Carmignani G: Radical nephrectomy for renal cell carcinoma: Long-term results and prognostic factors on a series of 328 cases. Eur Urol 1997;31:40-48
31. Castilho LN, Fugita OE, Mitre AI, Arap S: Port site tumor recurrences of renal cell carcinoma after videolaparoscopic radical nephrectomy. J Urol 2001;165:519

32. Saika T, Ono Y, Hattori R, Gotoh M, Kamihira O, Yoshikawa Y, Yoshino Y, Ohshima S: Long-term outcome of laparoscopic radical nephrectomy for pathologic T1 renal cell carcinoma. Urology 2003;62:1018-1023

33. Ono Y, Kinukawa T, Hattori R, Gotoh M, Kamihira O, Ohshima S: The long-term outcome of laparoscopic radical nephrectomy for small renal cell carcinoma. J Urol 2001;165:1867-1870

34. Portis AJ, Yan Y, Landman J, Chen C, Barrett PH, Fentie DD, Ono Y, McDougall EM, Clayman RV: Long-term followup after laparoscopic radical nephrectomy. J Urol 2002;167:12571262

35. Lotan Y, Gettman MT, Roehrborn CG, Pearle MS, Cadeddu JA: Cost comparison for laparoscopic nephrectomy and open nephrectomy: analysis of individual parameters. Urology 2002;59:821-825

36. Meraney AM, Gill IS: Financial analysis of open versus laparoscopic radical nephrectomy and nephroureterectomy. J Urol 2002;167:1757-1762

37. Lotan Y, Duchene DA, Cadeddu JA, Koeneman KS: Cost comparison of hand assisted laparoscopic nephrectomy and open nephrectomy: analysis of individual parameters. J Urol 2003; 170:752-755

38. Kim FJ, Rha KH, Hernandez F, Jarrett TW, Pinto PA, Kavoussi LR: Laparoscopic radical versus partial nephrectomy: assessment of complications. J Urol 2003;170:408-411

39. Matin SF, Gill IS, Worley S, Novick AC: Outcome of laparoscopic radical and open partial nephrectomy for the sporadic $4 \mathrm{~cm}$ or less renal tumor with a normal contralateral kidney. J Urol 2002;168:1359-1360

40. Van Poppel H, Bamelis B, Oyen R, Baert L: Partial nephrectomy for renal cell carcinoma can achieve long-term tumor control. J Urol 1998;160:674-678

41. Novick AC: Nephron-sparing surgery for renal cell carcinoma. Br J Urol 1998;82:321-324

42. Filipas D, Fichtner J, Spix C, Black P, Carus W, Hohenfellner $R$, Thüroff JW: Nephron-sparing surgery of renal cell carcinoma with a normal opposite kidney: long-term outcome in 180 patients. Urology 2000;56:387-392

43. Chan DY, Marshall FF: Partial nephrectomy for centrally located tumors. Urology 1999;54:1088-1092

44. Black P, Filipas D, Fichtner J, Hohenfellner R, Thüroff JW: Nephron-sparing surgery for central renal tumors: experience with 33 cases. J Urol 2000;163:737-743

45. Van Poppel H, Dilen K, Baert L: Incidental renal cell carcinoma and nephron sparing surgery. Curr Opin Urol 2001;11:281286

46. Richter F, Schnorr D, Deger S, Trk I, Roigas J, Wille A, Loening SA: Improvement of hemostasis in open and laparoscopically performed partial nephrectomy using a gelatin matrixthrombin tissue sealant (FloSeal). Urology 2003;61:73-77

47. User HM, Nadler RB: Application of FloSeal in nephron-sparing surgery. Urology 2003;62:342-343

48. Belldegrun A, Tsui KH, deKernion JB, Smith RB: Efficacy of nephron sparing surgery for renal cell carcinoma: analysis based on the new 1997 tumor-node-metastasis staging system. J Clin Oncol 1999;17:2868-2875

49. Gill IS, Matin SF, Desai MM, Kaouk JH, Steinberg A, Mascha E, Thornton J, Sherief MH, Strzempkowski B, Novick AC: Comparative analysis of laparoscopic versus open partial nephrectomy for renal tumors in 200 patients. J Urol 2003;170:6468

Received: April 28, 2004 